\title{
SOSIALISASI COVID 19
}

\author{
GUNAWAN \\ 9173770410151 \\ Sg9807473@gmail.com
}

1. Bentuk Kegiatan

> Mensosialisasikan Virus Covid 19.

2. Lokasi

$>$ Desa Bontocini.

3. Hari/Tanggal dan Waktu

$>$ Senin, 26 oktober 2020 pukul 16:00 - 17:45

4. Peserta yang Dilibatkan

$>$ Mahasiswa KKLP YAPTI JENEPONTO

5. Alasan Diadakannya

> Alasan Diadakannya yaitu karena masyarakat sepertinya mulai acuh terhadap protocol kesehatan yang dianjurkan sehingga kami berinisiatif untuk mengingatkan kembali mengenai bahaya virus Covid 19 agar masyarakat lebih berhati-hati lagi.

6. Tujuan dan Manfaat

> Tujuan dan Manfaatnya yaitu untuk mensosialisasikan bahaya virus covid 19 dan cara pencegahannya. agar masyarakat di desa Bontocini ini dapat menjaga kesehatan agar dapat terhindar dari virus berbahaya ini.

7. Deskripsi Kegiatan

> Kegiatan ini dilakukan dengan cara menempelkan brosur ke tiang listrik, papan informasi di tiap-tiap pos ronda di beberapa dusun, dan fasislitas umum seperti puskesmas desa. 
